\title{
1450 Zach and Karner
}

more, in neither of the index patients was $\dot{\mathrm{V}}_{\max 25}$ normalised after the bronchodilator. Correspondingly, another report on bronchodilator induced lung function changes in children who later died of asthma showed incomplete or absent responses for forced mid expiratory flow rates. ${ }^{5}$ These observations correlate with the concept of childhood asthma as a disease of the small airways. ${ }^{24} 25$ Inclusion of small airway related lung function measurements into the evaluation of paediatric asthma patients might be useful for better characterising disease severity.

In conclusion, we observed pronounced airway hyper-reactivity and severe underperception of airflow obstruction in two children with asthma who later died suddenly. These two observations do not suffice for a general explanation of sudden death in childhood and adolescent asthma. They do, however, suggest that repeated assessments of airway reactivity, complemented by the patient's subjective scoring of breathlessness, might be a promising approach towards better defining those children prone to sudden death from asthma.

\section{References}

1 Pearlman DS. Bronchial asthma. A perspective from childhood to adulthood. Am J Dis Child 1984;138:459-66.

2 König P. Asthma: a pediatric pulmonary disease and a changing concept. Pediatr Pulmonol 1987:3:264-75.

3 Mellis CM, Phelan PD. Asthma deaths in children - a continuing problem. Thorax 1977;32:29-34.

4 Rubinstein S, Hindi RD, Moss RB, Blessing-Moore J, Lewiston NJ. Sudden death in adolescent asthma. Ann Allergy 1984;53: 311-8.

5 Kravis LP, Kolski GB. Unexpected death in childhood asthma. A review of 13 deaths in ambulatory patients. Am J Dis Child 1985;139:558-63.

6 Carswell F. Thirty deaths from asthma. Arch Dis Child 1985;60: 25-8.

7 Sears MR, Rea HH, Fenwick J, et al. Deaths from asthma in New Zealand. Arch Dis Child 1986;61:6-10.

${ }^{8}$ Kravis LP. An analysis of fifteen childhood asthma fatalities. $J$ Allergy Clin Immunol 1987;80:467-72.

9 Strunk RC. Workshop on the identification of the fatality-prone patient with asthma: summary of workshop discussion. $J$ Allergy Clin Immunol 1987:80:455-7.

10 Zach MS, Polgar G, Kump H, Kroisel P. Cold air challenge of airway hyperreactivity in children: practical application and theoretical aspects. Pediatr Res 1984;18:469-78.

11 Zach MS, Polgar G, eds. Cold air challenge of airway hyperreactivity in children: dose-response interrelation with a reaction plateau. J Allergy Clin Immunol 1987;80:9-17.

12 Polgar G, Promadhat V. Pulmonary function testing in children: techniques and standards. Philadelphia: WB Saunders, 1971:186.

13 Zapletal A, Samanck M, Paul T. Upstream and total airway conductance in children and adolescents. Bull Eur Physiopathol Respir 1982;18:31-7.

14 Bateman JRM, Clarke SW. Sudden death in asthma. Thorax 1979;34:40-4.

15 Stableforth D. Death from asthma. Thorax 1983;38:801-5.

16 Benatar SR. Fatal asthma. $N$ Eng J Med 1986;314:423-8.
17 Reid LM. The presence or absence of bronchial mucus in fatal asthma. J Allergy Clin Immunol 1987;80:415-6.

18 Nguyen MT, Patterson K, Sly RM. Causes of death from asthma in children. Ann Allergy 1985;55:448-53.

19 McNicol KN, Williams HB. Spectrum of asthma in children - I. clinical and physiological components. Br Med J 1973;iv:7-11.

${ }^{20}$ Cushley MJ, Tattersfield AE. Sudden death in asthma: discussion paper. J $R$ Soc Med 1983;76:662-6.

2I Rubinfeld AR, Pain MCF. Perception of asthma. Lancet 1976;i: 882-4.

22 Burdon GW, Juniper EF, Killian KJ, Hargreave FE, Campbell EJM. The perception of breathlessness in asthma. Am Rev Respir Dis 1982;126:825-8.

${ }^{23}$ Hyatt RE, Rodarte JR, Mead J, Wilson TA. Changes in lung mechanics: flow-volume relations. In: Macklem PT, Permutt S, eds. The lung in the transition between health and disease. New York: Marcel Dekker, 1979:73-112.

24 Zapletal A, Motoyama EK, Gibson LE, Bouhuys A. Pulmonary mechanics in asthma and cystic fibrosis. Pediatrics 1971;48: $64-72$.

25 Hill DJ, Landau LJ, McNicol KN, Phelan PD. Asthma - the physiological and clinical spectrum in childhood: respiratory function studies in its assessment. Arch Dis Child 1972;47: 874-81.

Correspondence to Professor MS Zach, Univ. KinderKlinik Graz, Auenbruggerplatz, A-8036 Graz, Austria.

Accepted 11 April 1989

\section{Commentary}

\section{S McKENZIE}

\section{Rush Green Hospital, Romford, Essex}

Much has been written about the shortcomings in the care of asthmatics who have died in this country. The British Thoracic Association's review identified only 10 of 90 asthmatics in whom death was considered unavoidable. ${ }^{1}$ It would be impossible, however, to test whether management is more deficient in those who die than in asthmatics in general because of the difficulty in recruiting controls from the same practice. Carswell, in a review of 30 deaths in children, concluded that inadequate management had probably contributed to many of these deaths. ${ }^{2}$ Twelve of the 30 children had never attended hospital. Speight and colleagues in 1983 highlighted the problem of underdiagnosis and undertreatment of childhood asthma ${ }^{3}$; one wonders what overall effect educational programmes have since had in addressing this very serious problem. Two American studies of asthma deaths in children drew attention to the unsatisfactory psychosocial profiles of many of the patients and their families, which resulted in erratic treatment. ${ }^{45}$ It is difficult to compare the American experience with that in Britain because of 
the differences in the delivery of health care, but it is nevertheless clear that most children die in circumstances where there has been poor medical or parental supervision, or both.

The two children reported here were considered to have moderately severe asthma. The first, who died during the night, was known to suffer from night time wheezing; that is an extremely worrying feature. The second was known to have been absent from school in the year before her death and had had a cold in the previous five days. It is not mentioned whether adequate bronchodilators had been given during this time. The results of bronchial challenge testing in these two girls suggested that they were different from a group of children who also had moderately severe asthma and thus the two may have been identified as 'fatality prone'. These girls clearly had 'clinically labile' asthma but by implication no different from the others in the group.

Perhaps the classification of asthmatics into groups according to severity is no longer very helpful. If children miss school because of asthma or need emergency treatment then their asthma is troublesome and thus needs further attention. If exercise induced wheezing or night time waking are problems then treatment needs to be directed towards control of this clinical evidence of bronchial reactivity. Those caring for asthmatic childrenparents, physicians, teachers, and so on-need to know what triggers wheezing (for example, upper respiratory tract infections, parties, grandma's cat, school examinations) and need to know how to take effective steps to prevent it. The understanding and use of the home peak flow gauge will help identify abnormal diurnal variations in peak expiratory flow rate and draw attention to those children who are slow to perceive bronchoconstriction. The parents of every child who can use a peak flow gauge properly should know what his or her best possible measurement is-not necessarily the same as the mean value read off the chart that comes with the instrument (a common misunderstanding)—so that falls in readings can be identified early and acted upon. Most children can be taught to use a gauge properly before they start school, although they may not understand the significance of the readings. When children are known not to be receiving adequate parental supervision of their asthma, teachers should be encouraged to administer all drugs if necessary.

Once asthmatics are clinically stable and they and their families understand their disorder, and know what to do to prevent attacks, then it would be interesting to know if there are differences between them in the results of detailed lung function and bronchial challenge testing. It would also be interesting to know whether with intensive education perception of airway narrowing improves. If differences exist then a group can be singled out for further attention. With optimum clinical control morbidity would certainly be reduced but it would have to be seen if this was reflected in a drop in mortality. There will still remain a small group of very worrying asthmatics who despite all precautions, therapeutic and otherwise, will be at risk of sudden severe attacks. These patients and their families need to be drilled in emergency measures so that they are able to reach hospital before irreversible damage is done.

\section{References}

1 Research Committee of the British Thoracic Association. Death from asthma in two regions of England. Br Med $J$ 1982;285: 1251-5.

2 Carswell F. Thirty deaths from asthma. Arch Dis Child 1985;60: 25-8.

${ }^{3}$ Speight ANP, Lee DA, Hey EN. Underdiagnosis and undertreatment of asthma in childhood. Br Med J 1983;286:1253-6.

${ }^{4}$ Kravis LP. An analysis of fifteen childhood asthma fatalities. $J$ Allergy Clin Immunol 1987;80:467-72.

5 Strunk RC. Asthma deaths in childhood: identification of patients at risk and intervention. J Allergy Clin Immunol 1987; 80:472-5. 